Meta

Journal des traducteurs

Translators' Journal

\title{
Translation as a Means of Defining Grammatical Structures
}

\section{Dora Sakayan}

Volume 35, numéro 1, mars 1990

Actes du colloque international " La traduction proligère "

URI : https://id.erudit.org/iderudit/004019ar

DOI : https://doi.org/10.7202/004019ar

Aller au sommaire du numéro

Éditeur(s)

Les Presses de l'Université de Montréal

ISSN

0026-0452 (imprimé)

1492-1421 (numérique)

Découvrir la revue

Citer cet article

Sakayan, D. (1990). Translation as a Means of Defining Grammatical Structures. Meta, 35(1), 82-90. https://doi.org/10.7202/004019ar d'utilisation que vous pouvez consulter en ligne.

https://apropos.erudit.org/fr/usagers/politique-dutilisation/ 


\title{
TRANSLATION AS A MEANS OF DEFINING GRAMMATICAL STRUCTURES
}

\author{
DORA SAKAYAN \\ McGill University, Montreal, Canada
}

The aim of this paper is to show how translation can be used to cast light on the functions of certain linguistic entities and thus contribute to their proper grammatical description in a given language. I will focus on relative clauses and their equivalent structures across a group of languages in such a way as to demonstrate their systematic affiliations. To this end, I have turned to a representative group of non-finite verbal forms or verbids (derbays) in Eastern Armenian, and particularly to some instances of their use as revealed by translation into the major European languages (English, German, French and Russian). The contrast should be 'mutually advantageous' to the study of both Armenian and the languages selected. The paper deals with Armenian constructions featuring adjectival participles which, with or without actualizers, can perform functions similar to those of relative clauses in a variety of positions in a sentence.

There are ten non-finite verbal forms or derbays in Armenian. This set is interpreted in the Armenian linguistic literature (Abrahamyan 1953, Jahowkyan 1975, Assatryan 1983, Sakayan 1986 et al.) by and large as follows:

1. Derbays belong to the verbal paradigm;

2. There is no one-to-one correspondence between any of the derbays and similar formations in other Indo-European languages, such as English gerunds and participles, the Partizip $I$ and II in German, the gérondif and the participe passé in French and 'pričastie' and 'deepricastie' in Russian. This asymmetry is similar to that between the Armenian infinitive and any infinitive in the languages mentioned above.

3. Armenian has both 'independent' and 'dependent' derbays. The latter can be used only within the conjugation paradigm as the stable components of analytical verbal finite forms. The independent group consists of

1) the infinitive, for example, grel/kardal - 'to write'/ 'to read' where -el and -al are the most common infinitive suffixes;

2) three derbays with adjectival function:

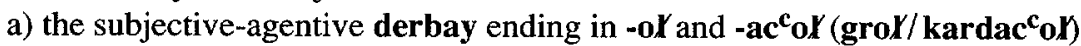

b) the resultative-perfective derbay ending in -ac and $-\mathbf{a c}^{\mathbf{c}} \mathbf{a c}$ (grac/ $\mathbf{k a r d a c} \mathbf{c}^{\mathbf{a c}}$ )

c) the future-gerundive derbay ending in -elik ${ }^{\mathbf{c}}$ and -alik ${ }^{\mathbf{c}}\left(\right.$ grelik $^{\mathbf{c}} /$ kardalik $^{\mathbf{c}}$ )

3) two derbays with adverbial function:

a) the temporal derbay: grelis / kardalis

b) the modal derbay: grelov/ kardalov ${ }^{1}$

Let us now focus on the three derbays with adjectival status and on some established views on them in the Armenian linguistic literature. I will test the validity of these views by the method of translation into several European languages. Ultimately such an approach could lead to a comprehensive grammatical description of these formations.

Of all the strategies available for transforming predicative structures into attributive structures, Armenian makes use of two: relative clauses and participles. It deranks a sentence into the attribute of a nominal phrase in the following ways: 
1) by transforming an independent sentence into a prototypical relative clause. In Armenian, that entails the use of the relative pronoun 'or(d) ${ }^{2}$ to introduce the relative clause. There is no change in the word order of the underlying independent sentence. As a rule, the relative clause follows the head word (thus constituting a postnominal relative clause):

(1) mard $\partial$, or $\partial$ namak ê grum

(man-the who letter is writing)

'The man who is writing a letter'

(2) by transforming the sentence into a participial construction which precedes the head word:

(2) namak grol mard 2

(letter writing man-the)

'The man who is writing a letter'

For all their considerable difference in form, both attributive constructions, or $\partial$ namak ê grum in (1) and namak grol in (2) fulfil the same restrictive function. In other words, both "delimit the potential referents of the head word," in this case mard "the man" (Comrie 1981: 131) ${ }^{3}$. On the basis of this common function, the recent literature on language universals has come to adopt a "largely syntax-free way of identifying relative clauses in an arbitrary language" and to give a "semantically based definition" of them (Keenan/Comrie 1977: 63).

This prompted the universalists to consider participles, which are interchangeable with relative clauses ( $\mathrm{RCs}$ ), to be 'relative participles' (RP) 4 . Their approach is justified by the observation that structures resulting from these two different strategies are interchangeable not only within a single language, but also across a number of languages. It applies more fully when one of a pair of languages lacks the second choice available to its counterpart. Ironically enough, Armenian grammars do not discuss these functionally related entities in the same or even contingent contexts. Moreover, they neglect this obvious semantic affiliation.

And this is despite the fact that in Armenian both strategies are very productive. They are stylistically distinct from each other, the RCs being more common in the written and the RPs in the spoken language.

As we know, different languages differ in the number of positions available for relativizing the head word of a $\mathrm{RC}$. The subject position stands first in relativization. Some languages can relativize only in the subject position, as in the case of Malagasy, a Western Malayo-Polynesian language (Keenan/Comrie 1977: 68):

(3) ny mpianatra izay nahita ny vehivavy

(the student that saw the woman)

'The student that saw the woman'

In other languages, such as Finnish (Karlsson 1972: 107) one of the main relativization strategies is restricted to the SU and DO positions. Compare the relativization in the DO position.

(4) Näkemäni poika tanssi pöydällä

(I-having-seen boy danced on table)

'The boy that I saw danced on the table'

The first attempt to measure the potential of a relativization strategy in a given language was made by Keenan/Comrie (1972/1977). The accessibility hierarchy (AH) they 
postulated "expresses the relative accessibility to relativization of NP positions in simplex main clauses" (Keenan/Comrie 1977: 66):

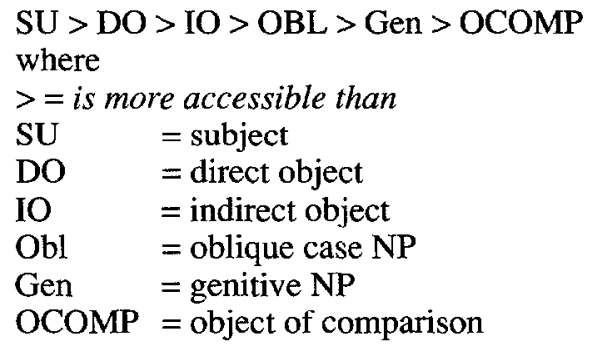

There are $\mathrm{AH}$ constraints which impose the following conditions:

(1) A language must have access to the subject position; hierarchy;

(2) A RC-forming strategy must have access to a continuous segment of this

(3) Once a strategy is exhausted at any point on the $\mathrm{AH}$, access to any lower point is forfeited (Keenan /Comrie 1977: 67).

Thus, if a language can relativize in any given position on the $\mathrm{AH}$, it must necessarily be able to relativize in any higher position. As a rule, there should be no gaps on the AH (Keenan/Comrie 1977: 69).

The two Armenian strategies of relativization we are dealing with vary with respect to their accessibility to relativization. The postnominal RC strategy appears in all positions on the $\mathrm{AH}$; it enjoys this privilege thanks to the full declension paradigm of the relative pronoun or(2). By way of contrast, the RP strategy does not enjoy the same full access to all NP positions. Nevertheless, some initial positions on the AH, i.e. the SU and DO positions, are coded in the participles by the special suffixes -ol, -ac and -elikc Whereas RPs ending in -ol always code the SU position, formations in -ac and -elik ${ }^{\mathbf{c}}$ demonstrate a larger range of capacity: depending on the valency of the underlying verb, they can code the SU, DO and other positions. This crucial distinction was revealed by intra- and interlinguistic translation; it had escaped the attention of unilingual Armenian studies. There adjectival participles with different suffixes are considered to express only temporality, and particularly 'non-situational' time as opposed to the 'situational' (Jahowkyan 1975) time of finite verbal forms. According to that view, each pair of adjectival participles forms a temporal opposition by expressing:
a) simultaneity $(-\mathbf{o l} /-\mathbf{a c} \mathbf{c} \mathbf{l})$
b) anteriority (-ac/-acc $\mathbf{a c})$
c) posteriority (-elik $\mathbf{c}$-alik ${ }^{\mathbf{c}}$ )

Participles ending in the suffixes -ol vs. -ac, for example, are said to form the temporal opposition simultaneity vs. anteriority.

A closer examination based on translation into other languages reveals that this temporal classification does not always apply.

When interpreting adjectival derbays from whatever standpoint, including their socalled temporal opposition, the grammatical and semantic features of each individual underlying verb must be taken into consideration.

For instance, neutral verbs tend to support the temporal opposition factor:

Compare the participials from anc ${ }^{c}$ nel to pass:

(5) anc ${ }^{\text {nor }}$ tarin the year which passes

(6) anc ac ôrero the days which have passed

(7) anc $^{\mathbf{c}}$ nelik ${ }^{\mathbf{c}}$ žamanak $\partial$ the time which will pass 
The same holds true for passive formations derived from transitive verbs by the

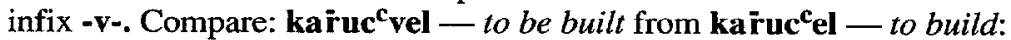

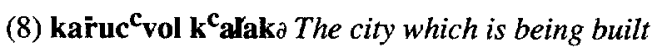

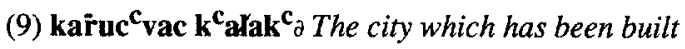

(10) kar̆uc $^{\mathbf{c}_{\text {velik }}} \mathbf{k}^{\mathbf{c}}$ alak The city which will be built

These examples do convey the notion of time, namely simultaneity (5) and (8), anteriority (6) and (9) or posteriority (7) and (10). Therefore the economical constructions of RPs can compete with the comparable RCs employing finite verbs. Thus far the established temporal classification remains valid, though perhaps it might be better to think of the opposition in terms of aspect, i.e. perfectivity vs. imperfectivity, rather than in terms of tense.

One thing is obvious: as derivatives from intransitive verbs, all these formations code the single argument available in the underlying sentence, i.e. the head word in the subject position. Therefore, it is obvious that a simple change of suffixes cannot alter any position on the AH.

An entirely different picture emerges when we turn to the transitive verbs. Consider the participials derived from a transitive verb, such as tesnol vs. tesac from tesnel to see. Here the -ol and -ac formations form a regular opposition of quite a different nature: that of voice (active vs. passive) or, to be more specific, relativization in the subject vs. object position. In this case, the suffixes -ol vs. -ac are to be defined as separate relativization markers designed for the focusing of each of the two arguments governed by the underlying verb. Consider the transfomation of sentence (11) into (12) and (13):

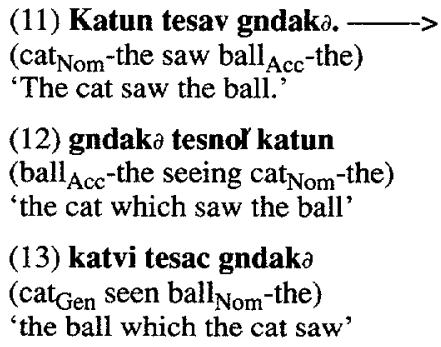

Note that each of the arguments can be focused by different relative participles: the one ending in -ol is subject-centered and therefore relativizes in the SU position, whereas the one in -ac is object centered and can therefore relativize in the DO position. The clear distinction of SU and DO positions can be exemplified by (14) and (15):

(14) hors spanol mard

(father ${ }_{\text {Acc }}$-mine killing man $_{\mathrm{Nom}^{-}}$-the)

'The man who killed my father'

'L'homme qui a tué mon père'

'Der Mann, der meinen Vater getötet hat'

'Čelovek, kotoryi ubyl moego otca'

(15) hors spanac mard

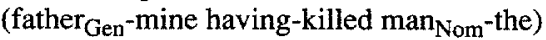

'The man who my father killed'

'L'homme que mon père a tué'

'Der Mann, den mein Vater getötet hat'

'Čelovek, kotorogo ubyl otec' 
It is remarkable that both -or and -ac formations (compare spanor vs. spanac) are rendered into English, German, French and Russian in the same tense, i.e. in the past in the RC. Conversely, all the above translations reveal that $\mathbf{- o l}$ and -ac code different positions: -ol codes the SU and -ac the DO position.

Whereas Armenian accomplishes this task by means of different relativization markers in the participles, European languages resort to other tactics to code the SU and DO positions:

1. German and Russian make use of relative pronouns with +case-coding (Keenan/Comrie 1977: 67); coding.

2. English makes use of relative pronouns and different word order with -case

3. French uses both different relative pronouns and different word order.

As we have seen, while deriving from a predicative structure an attributive participle, adjectival derbays can focus on the subject of the underlying sentence, and thus relativize the subject position. Transitive verbs accomplish this exclusively by means of the suffix -ol. When these derbays focus on a direct object, however, they relativize it only by the suffix -ac.

As we descend on the AH, the capacity to relativize by RPs decreases. For one thing, a RP is unable to realize the IO position. As for other positions, those lower on the $\mathrm{AH}$, and particularly the $\mathrm{Obl}$ and the Gen, they must be "promoted"5 to the DO position in order to be relativized. For this purpose the suffix $-\mathbf{a c}^{6}$ designed for the direct object, can be used. Compare the relativization procedure in the Obl position:

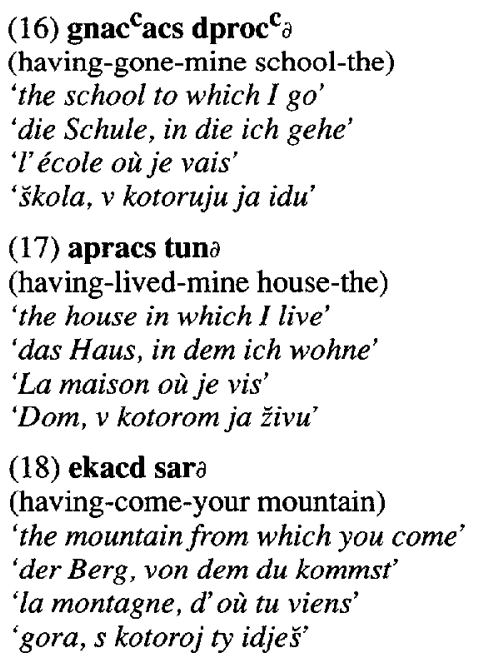

Interestingly enough, it is the intransitive verbs (in the examples above: gnal - 'to go', aprel- 'to live' and gal - 'to come') whose participles code the Obl positions of NPs by appearing with a suffix designed to express relativization in the DO position.

Another position, much lower on the AH, to which Armenian RPs have access is the Gen position. To be sure, in order to be relativized in the genitive, a head noun must express an item in its relation to an inalieniated part of it. Compare:

(19) Terevnera $\mathbf{t}^{\mathbf{c}_{\mathbf{a p}}} \mathbf{c}_{\mathbf{a c}}$ cara $\partial$

(leaves-the having-fallen tree)

'The tree whose leaves have fallen' 
(20) $\mathbf{T}^{\mathbf{c}}$ ever $\partial$ kotrac $\mathbf{t}^{\mathbf{c}}$ rcun $\partial$

(wings-the having-broken bird-the)

'The bird whose wings are broken"

Once again, it is the participle ending in the invariable suffix -ac designed for the DO (compare tapcac fallen and kotrac broken) which is used here to code the Gen position of the head words cara the tree and $\mathbf{t}^{\mathbf{c}}$ rčuna the bird.

The close affiliation between all types of restrictive RCs becomes clear when we view them through the prism of the Armenian RPs, especially the one using the polyfunctional suffix -ac. But this is by no means the only advantage to be gained from such an approach. For languages also make use of RCs other than the attributive.

Given their frequent use in the attributive function, RCs are widely, almost universally considered synonymous with attributive clauses and restricted to that one notion. As a result, other functions of $\mathrm{RCs}$, such as the subject, object, predicate functions, are often neglected, if not to say ignored. At best, they are discussed at random, as an afterthought to their respective functions in sentence. The attributive bias has led grammarians to overlook the fact that the notion 'relative' in the term 'relative clause' refers to a way of connecting clauses no less important than that of their connection with and without conjunctions. Hence my second aim in this paper: through another Armenian strategy of forming RCs, namely RCs in a function other than the attributive, I will attempt to show just how closely connected all types of RCs are. In order to do so, I will follow the rise of Armenian RPs from a lower to a higher level of nominalization.

None of the RCs and their equivalent RPs discussed above represent independent sentence members, but only parts of such members, i.e. their modifiers. Like their participial equivalents, RCs belong to the class of relational expressions presented by Seiler (1975) and later discussed by Lehmann (1984: 149). According to Seiler and Lehmann, relational expressions are unsaturated and must be used with arguments in order to acquire reference value. Relational expressions cannot refer directly to reality; they are, as defined by Bally (1944: 28), virtual expressions. As such, they create in the sentence openings which must be occupied before they can form, together with the argument, an absolute expression amenable to actualization. For example:

(21) mard $a$ orin sirum em

(man-the which Acc $_{\text {loving am) }}$

(22) siracs mard $\partial$

(having-loved-mine man-the)

both (21) and (22) to be translated: the man who I love

In these nominal phrases, it is the combination of the head word mard $\partial$ - 'the man' together with the relational expressions, the RC: orin sirum em or the RP: siracs 'who I love', which makes them a referential expression.

But these Armenian participials can also be used without a head word, i.e. as absolute expressions. According to the agglutinative properties of the Armenian inflexion paradigm which set it apart from other Indo-European languages, they take on the features of the head word and appear agglutinated with actualizers (the definite article or the deictic-possessive article), with case markers and plural markers. Thus they can express such categories as determination, case and number. In this manner, they can occupy, with and without connectives, all positions typical of a nominal phrase in a sentence. They can also carry negation markers and, like RCs, express affirmative vs. negative modality. 
Examples in -or:

with an actualizer, here the definite article $-\partial$ :

(23) mtacolo

(thinking-the)

'(he) who thinks'

'wer denkt'

'celui qui pense'

'tot, kto dumaet'

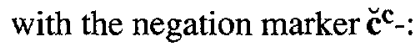

(24) čcmtacolo

(not-thinking-the)

'(he) who doesn't think'

'wer nicht denkt'

"celui qui ne pense pas'

'tot, kto ne dumaet'

with both the plural marker -ner and the definite article - $\partial$ :

(25) mtacoĺner $\partial$

(thinking ${ }_{\text {Plur }}$-the)

(having-seen-the)

'those who think'

'diejenigen, die denken'

'ceux qui pensent'

'te, kto dumaet'

Forms in -ac are even more productive:

with an actualizer, here the deictic-possessive -s:

(26) Tesacs

(having-seen-mine)

'what I have seen'

'was ich gesehen habe'

'ce que j'ai vu'

'to, čto ja videl'

with the negation marker $\check{\mathbf{c}}-$ :

(27) $\breve{\mathbf{c}}$ tesacs

(not-having-seen-mine)

'what I have not seen'

'was ich nicht gesehen habe'

'ce que je n'ai pas vu'

'to, čto ja ne videl'

with the plural marker -ner-:

(28) tesacners

(having-seen Plur-mine)

'everything that I have seen'

'alles, was ich gesehen habe'

'tout ce que j'ai vu'

'vsje, čto ja videl' 
When declined as a regular noun, they can attain great flexibility in sentence, appearing in all sentence positions. Like regular nouns, their case can be governed by adpositions. Compare their use with the postpositions masin about in (29) and bacci besides in (30).

With the case marker $-i$ for the genitive:

(29) $\check{\mathbf{c}}^{\mathbf{c}}$ mtacolneri (masin)

(not-thinking ${ }_{\text {PlurGen }}$ about)

'about those who do not think'

'über diejenigen, die nicht denken'

'à propos de ceux qui ne pensent pas'

'o tex, kotorye ne dumajut'

with the case marker -i $\breve{c}^{\prime}$ for the ablative:

(30) tesacneric $c_{s}\left(\right.$ bac $^{\left.c_{i}\right)}$

(having-seenPlurAbl-mine besides)

'besides what I have seen'

'außer dem, was ich gesehen habe'

'outre ce que j'ai vu'

'krome togo, čto ja videl'

Compare also the diversity of their functions in sentence:

(31) nran tvacis gin $\partial$

(him having-given $\mathrm{Gen}_{\mathrm{-mine}}$ price)

'the price of what I gave to him'

'der Preis dessen, was ich ihm gegeben habe'

'le prix de ce que je lui ai donné'

'cena togo, čto ja emu dal'

(32) Zgušac $\boldsymbol{c}_{\text {ir }} \breve{c}^{\mathbf{c}_{\text {artahaytvolneric }}} \mathbf{c}$.

(beware not-expressing-themselves PlurAbl $_{\text {) }}$

'Beware of those who do not express themselves.'

'Hüte dich vor denen, die sich nicht ausdrücken.'

'Garde-toi de ceux qui ne s'expriment pas!'

' Beregis' tex, kto ne vyskazyvaetsja.'

As a rule, this type of relative NP has no parallel structure in the European languages and must be rendered into them by means of RCs in the subject, object and all other positions typical of a NP in a main sentence.

In the Armenian linguistic literature this type of formation is treated as various forms of substantivization. Nowhere do we find even the slightest indication that such formations, viewed intra- and interlinguistically, ought to be considered as forms synonymous to relative clauses in main sentence positions. No less astonishing is the lack of any distinction drawn between substantivization and nominalization. In his book "General Armenian Lexicology" (1984), Axayan points to a number of lexicalized derbays, such as grol - 'writer', usanol - 'student', xorovac - 'barbecue'. Alayan's examples clearly represent substantivization, for indeed they do have entries in contemporary lexicons. However, derbay formations play a much more significant role in parole derivation, which emerges on the text level on an ad hoc basis. These appear with actualizers, but are never integrated into the lexicon. I class these cases as nominalizations as opposed to substantivizations. Like Jahowkyan, I consider all derbays as transformations from finite verbal forms (Jahowkyan 1975). I go further, however, by distinguishing two degrees of transformation: 
The first degree transforms an independent sentence into a relative participle; The second degree transforms a relative participle into a relative NP.

Compare the first degree transforming (33) into (33a)

(33) mi ban kerar. $\rightarrow$ (33a) keracd ban $a$

(one thing ate-you) (having-eaten-your thing)

'You ate something. $\rightarrow$ the thing that you ate'

and the second degree transforming (33a) into (33b):

(33b) keracd 'what you ate'

(having-eaten-your)

This distinction makes it easy to follow the transition from a relative participial to a relative NP and to see how closely related these two formations are.

Paraphrasing these short Armenian nominal phrases into elaborate relative clauses in other languages proves to be an excellent means towards the systematic description of all the functions that such a polyfunctional and economical program can ensure for in Armenian. On the other hand, using Armenian participle constructions as a starting point, a diversity of linguistic material in any of the European languages mentioned above, scattered in different areas of grammatical description or entirely neglected, can be classified as a series of semantic-syntactic patterns united under the single heading of relative clauses in all sentence positions.

\section{NOTES}

1. The treatment of forms ending in -elov/-alov as modal derbays is a new approach. It was first mentioned in a paper presented by D. Sakayan in 1987, at the Fourth Conference of AIEA (Association Internationale des Études Arméniennes) in Fribourg (Switzerland).

2. Armenian or(a) is primarily an interrogative pronoun: or which? and ord which one? Secondarily or corresponds to the English that as both a subordinate conjunction and a relative pronoun, ora corresponds to the English relative pronoun who.

3. Obviously, the present discussion is limited to restrictive relative clauses.

4. See particularly the treatment of Relativpartzipien in Lehmann 1984.

5. For promotion to a higher level on the AH in order to breach a gap on it, see Keenan/Comrie 1977:69.

6. -elik ${ }^{c}$ too can code different positions on the AH. Due to its semantic complexity, the functions of the suffix -elik ${ }^{\mathbf{c}}$ will not enter the present discussion.

\section{BIBLIOGRAPHY}

ABRAHAMYAN, A. (1953) : Hayereni derbaynerə ev nranc ${ }^{c}$ jevabanakan nšanakut ${ }^{c}$ yuñ (Armenian derbays and their morphological significance), Yerevan, Armenian Academy Press.

ASSATRYAN, M. (1983): Žamanakakic ${ }^{c}$ hayoc ${ }^{c}$ lezu (Modern Armenian), Yerevan, Yerevan University Press. BALLY, Ch. (1944): Linguistique générale et linguistique française Berne, A. Francke.

COMRIE, B. (1981): Language Universals and Linguistic Typology, Chicago, University of Chicago Press.

JAHOWKYAN, G. (1975): "Zamanakakic c hayereni andem bayerd, "derbaynerd" (Non-finite verbs in modern Armenian: the 'derbays'), $B E H, 1975 / 3,40-54$.

KARLSSON, F. (1972): "Relative Clauses in Finnish", in P.M. Peranteau et al. eds. The Chicago Which Hunt, Papers from the Relative Clause Festival, April 13, 1972, Chicago, Chicago Linguistic Society, pp. 106-114.

KEENAN, E. L./B. COMRIE (1977): "Noun Phrase Accessibility and Universal Grammar", Linguistic Inquiry, 8/1: 63-99.

LEHMANN, Chr. (1984) : Der Relativsatz, Tüibingen, Narr.

SAKAYAN, D. (1986): Formen der Textkohärenz. Nominalisierung als sententiale Anapher im Ostarmenischen, Tübingen, Narr.

SEILER, H. (ed.) (1975) : Linguistic workshop III. Arbeiten des Kölner Universalienprojekts 1974, München, Fink. 